\title{
THE CONCEPT OF THE IDEA OF FREEDOM IN ANCIENT AND MEDIEVAL PHILOSOPHY
}

\author{
Rakhimdjanova Dilnavoz Sunnat qizi \\ National University of Uzbekistan named after Mirzo Ulugbek, Tashkent, Uzbekistan.
}

\begin{abstract}
The article gives the formation and development of the idea of freedom in the ancient and medieval European philosophical tradition. On the basis of the analysis it becomes clear that the modern understanding of the idea of freedom, as well as the ideas of law, justice and civil society take their roots in the philosophy of Antiquity and Middle Ages. The subsequent movement of philosophical and political thought only develops in more detail both theoretical categories and "applied" aspects of this notion, on the basis of which modern democratic states are built.
\end{abstract}

Keywords:

philosophy, the idea of freedom, cultural universals, ancient polis, mythology, antiquity, the Middle Ages, freedom of will, person, society, good, God, choice.

Article Received: 18 October 2020, Revised: 3 November 2020, Accepted: 24 December 2020

\section{Introduction}

The contemporary philosophical notions of freedom, including the notion of freedom as a cultural universal date back to the period of antiquity. The system of polis served as a basis for the formation of the rational mentality, personal discourse and its individual attributes by asserting the rights and freedoms of a part of polis' citizens. The two mutually-exclusive morality of such a polis society: one being the antagonistic (based on competition) and the other communal gave birth to the notion that human rights and freedoms are interrelated.

The antique society, in the course of history, both on the level of daily consciousness, and on the level of the system of rights and the philosophical doctrines, has been subject to certain changes. The ancient philosophy illustrates the main interrelationship between human freedom and rights and the normative and regulative character of this notion.

According to historians of philosophy, originally neither the Greek word "elevupeia", nor the Latin "libertas" had a specific philosophical meaning. In the thinking of the ancient Greeks and Romans, the notion of freedom was not expressed either thematically or terminologically [6, 1064].
The main interest of ancient Greek thinkers at that time was aimed at understanding such concepts as necessity, fate or chance. For example, in the works of Hesiod or Anaximander, we can find fragments that speak about fate as the domination of divine power in human life. And this, in turn, has already given us grounds to interpret these reflections as reflections on the possible freedom or failure of human actions and deeds.

The views on human freedom in antiquity, like in many other archaic societies rooted in certain myths. Ancient Greek mythology is a collection of myths about the struggle of various divinities or gods and goddesses for the domination over the kosmos, and anthropogenic myths include various problems of human dominance and freedom. The relationship and competition of divinities, such as Chaos, Chronos, Uranus, Zeus, and their wars with various Titans symbolically illustrates the fact that majority of cultural and social norms, including the notion of freedom itself subjected to changes over the time.

The formation and confirmation of the authority of the Olympic Pantheon was reflected in the appearance and consolidation of the principles of legitimacy, justice and obedience. The notion of "Dike" (or "Dice")is reflected in the 
will of Zeus in the form of the supreme defender of general justice. Its violation is considered as illegal and antisocial act and as an act of overstepping the divine authority. With this, one can agree with A.A. Takho-Godi, who argues that ancient Greek mythology depicted the specific life of the ancient polis in a figurative-symbolic form [11].

The emerging polis laws and legal norms, the skills of communication and collective decision-making, emerged in the form of a boundary of opportunity, where cross-cultural exchanges led to the expansion of that boundary. The formation of freedom as a cultural universal in the ancient Greek polis by adding external conditions to the ranks of internal factors took place in the process of understanding the connection between freedom and its limitation. First of all, through the formation of political and legal norms, state regulations.

The concept of "being free" arises much earlier than the notion of freedom itself. To be free, as far back as Homer was concerned, meant to live on one's own land and not be under anyone's domination - as opposed to prisoners of war, who were considered slaves.

After Homer, the concept of "being free" has already firmly rooted in the word usage of the Greek polis. It means that the policy itself represents a free land, and a free person is one who lives on the land of the policy. In the Greek policy the mind should dominate, and violence is limited to system of the right.

Besides, the change of accents in the understanding of human freedom manifested itself also in the fact that the opposite concept in relation to the concept of "free man" is not the concept of "slave" but the concept of "non-Greek" or "barbarian". At the same time, the concept of freedom is grounded in the idea of God and does not mean a state of anarchy, where everyone is free to act at his or her own discretion, but the equality of all citizens of the policy before the law.
Along with this notion of freedom, which is directly related to the policy as the guarantor of human freedom, in ancient Greek philosophy one can find the notion of free will as a designation of individual freedom of a person. In Homer's case, the free man is the one who is not subject to any external coercion and acts according to the wishes of his own nature.

Democritus, one of the first thinkers of antiquity to draw attention to the connection between freedom and the rule of law, argued that the interests of the state take precedence over the interests of the individual. "Public affairs should be considered more important than other affairs; Everyone should strive for the prosperity of the state, not to achieve the glory he deserves, not to gain power beyond the level that benefits the common cause ..."[12, 360]. From the point of view of the founder of ancient atomism, living in a democratic society, albeit among the poor is better that being rich in a monarchy, "just as freedom is better than slavery" $[12,361]$. He deals with the problem of freedom in the context of the confrontation of civil and slave possibilities. They are not only interconnected, but also contradictory to each other. "How! Is freedom available with the help of slavery? It could be. These two edges intersect ... There are such difficult situations that one can maintain one's freedom only at the expense of the freedom of others, and a citizen can be absolutely free when the slave is a slave to the last degree. This is the situation in Sparta!" $[13,223]$.

Democritus also argued that freedom is inextricably linked to legal and political rules. Because "the law tries to assist human life. But this can be achieved only when the citizens themselves want to live a happy life: for those who obey the law, the law is only a sign of their personal goodness" [14, 361].

If slavery was seen as something that existed in ancient society, then the problem of freedom had nothing to do with the state of slavery; the rights and freedoms belonged only to those who had citizenship. In particular, the 
responsibility rested solely on them. As noted above, freedom and law were firstly defined in a political and legal context. If, in the political aspect, freedom is defined and understood as a clear algorithm of action necessary to wipe out and solve social problems, then there are no formalized rights of the individual in the legal perspective. This is where the interests of the state and the community come to the fore.

The use of the concept of "freedom" in the philosophical sense is first encountered with Sophies, when the law (Nomos) is radically opposed to nature (Physis). The sophists seem to "separate" the concept of freedom from the polis and polis democracy and oppose it to the polis. Thus, freedom begins to be understood as the "inner freedom" of an individual. From now on, the state of freedom can be achieved even regardless of law or politics.

Thus, freedom begins to be understood as achieving harmony between the logo and nature $[3,435]$. It is the Stoics who have the tendency to view freedom as an "internal" concept of the human being (especially the Epicyte). It was an attempt to take the notion of freedom out of the sphere of political usage and consider it as a dichotomy of "inner- outer" freedom, which was later continued in the European philosophical tradition. This dichotomy, but already in a more acute form, was formulated later and was taken in the Middle Ages of philosophy.

"Nature" in the sophists' sense is something that unfolds itself without any external coercion. What nature creates in its freedom is necessary, unlike the laws were created by man. And although a person strives in his life to achieve pleasure, not every pleasure should be sought. Democritus believed that it is worth of justifying to strive only for the morally beautiful.

Notions of freedom, its interrelationship with civic duty and responsibility are formed in the field of politics. Only in the classical period of the development of ancient philosophy was Socrates one of the first to focus on the inseparability and unity of morality and politicality in freedom, individuality and the community, its creative character and its connection with choice. It is impossible to understand freedom without an analysis of Socrates'views moral choice and disobedience to moral norms. Because, people have a perceptive ability that reflects their moral views, which helps in the choice between good and evil. When a man is before a choice, in the eyes of Socrates he appears to be an active being, and as a result, he is confronted with possible alternatives. At the same time, the basis of human choice is responsibility and moral evaluation: "Those who err in the choice between good and evil do not understand the responsibility sufficiently and make mistakes" $[15,183]$.

In particular, while freedom is shaped as a cultural universal in the conditions of ancient police life, it not only becomes a component of the algorithms of a citizen's activity, but also undergoes philosophical reflection. Focusing on the moral side of human problems, Socrates associated freedom not only with choice, but also with virtue, goodness, and morality. In the philosophical dialogues of Socrates, goodness is considered one of the dominant choices of behavior or activity as the basis of morality, that is, it implies not only the right to choose, but is responsible for the choice itself as well as its consequences. From the standpoint of Socratic ethics, a symbiosis of individuality and community emerges in the reflection of freedom. For the first time, the thesis that the limitation of human freedom bythe freedom of other citizens is formed.

\section{Materials and methods}

According to Xenophon, an abbreviated understanding of freedom is "doing the best". This understanding of freedom already contains knowledge of what is "the best" and how a person's moral choices are made. This is where, for the first time in philosophy, choice is understood in the sense of moral choice.

To know "better" requires a special ability - the "art of measuring the soul". It can be argued 
that Socrates developed, so to speak, "educational" point of view - everyone is equally looking for the good, but not everyone knows what it is. Mind should release a person from lower motives and desires, and thus lead him to good.

In the philosophical teachings of the schools of Socrates, Cynics and Cyrenaics one can distinguish different interpretations of civil liberties. From the point of view of the Cynics, man is sinful and cruel by nature, so he cannot attain freedom. The culprit for all this is the limited resources of nature. In this respect, "the sinner is subject to his passions and loses the most precious treasure of his soul - freedom" [16, 37]. Cynics defined the question of pure freedom through their individual responsibility to society throughout their individual lives. According to the Cynics, autarky is pure freedom. It includes the independence and autonomy of the individual, which are "more valuable than the blessings that the ignorant pursue" $[17,14]$.

The representatives of the Cyrenaic school put forward the idea of the natural and primordial origin of freedom in harmony with the idea of equality. Rejecting generally accepted cultural and moral norms; the Cyrenaics (Theodore, Gegesius) argued that they were contrary to human nature. Delight has been declared as the perfect blessing. Achieving them is through perception and goodness.

We can agree with A. F.Losev: "If we discuss the primary basis of the Cyrenaic philosophy, then it is the desire to build a spirit of freedom for man. In this respect, they are no different from the views of Socrates at all. Nevertheless, they have a completely different configuration of the concept than Socrates, and the opposite view of the Cynics. If the vital instincts in the Cynics were left in completely arbitrary hands, the mind used this arbitrariness to organize its independence from them. We know that in practice this would lead to the abolition of vital instincts, or, in the absence of understanding the interaction with the mind, they would become a purely physical and mechanical process. The Cyrenaics also built on the freedom and arbitrariness of the vital instincts, which also provided for the whims and zigzags of life's chaos. The Cyrenaics, along with the Cynics, did not set the sole purpose of the spontaneous chaos of life, but the freedom of the soul, manifested in the form of a reaction to this chaos. However, both of them later deviate from this idea" [18, 242].

The Cynics took Socrates' teachings exclusively from the moment of autarchy and developed them towards a radical rejection of all human needs. This was especially evident in Diogenes Sinopsky, who spoke about the development of "inner freedom" of Nidivide by increasing radical independence from both external (violence) and internal (desire, passion) manifestations of coercion. In general, we can say that ancient Greek ideas of freedom were closely linked to the idea of fate, destiny or fortune.

Plato's concept of freedom is defined almost exclusively within the framework of polysynthesis of freedom as existence of good. Good is a perfect concept, and it also makes being perfect.

The concept of autarky (independence) used in the language of the policy is also the basic definition of freedom: free is the person whose actions are aimed at achieving the good, because the good in his autarky and carries with its freedom.

A person's soul can be ordered through self-control and reflection, just as a policy can be ordered through national assembly and unity. Freedom, therefore, is not the independence of an individual from society, but the firm possession of himself and the pursuit of good. In Plato's later dialogues the highest form of freedom is freedom as friendship - and it is realized in the society, in the "perfect" society of the polis. As well as love to oneself, which is developed by every citizen, friendship is a perfect reflection of the autarchy of the good as kicking itself $[6,1068]$. 
Socrates and Plato have formed a new approach to the categories of freedom and responsibility: their imputation is more firmly "correlated" with the arbitrariness of individual decision and action, morality is a major moral achievement or good, and freedom is already interpreted as the ability to do good $[2,504]$.

Plato's responsibility has not been a completely moral category yet; however, it is no longer considered in the relationship between man and nature and space alone.

Men as an intelligent creature of the nature, unlike animals, is capable of responsibility because he has the knowledge of morality and duty. Virtuality of action is identified with the intelligence of the individual.

In order to justify the deity, Plato develops his theodicy, according to which every soul chooses its own path and destiny, but at the same time is responsible for its own choice ("It is the culpability of the elector; God is innocent"). It should be noted, however, that Plato was far from ascribe individual to his autonomy.

According to Plato, human freedom is revealed in his ascetic state, in his striving for knowledge and good.

In historical perspective it can be noted that the influence of Plato's ideas was not enough to make more acceptable only by using the notion of fatalism to the perception of such a "brave" for the time thoughts as freedom of human actions or freedom of human will.

This is not surprising, because Plato does not manage to solve the "paradox of responsibility", he could not explain how it is possible to choose "own character", without, on the one hand, not to be determined through some "protoharak" and, on the other hand, in his choice not to follow randomness or arbitrariness [5, 15].

Aristotle opposes Plato's concept of freedom as an autarchy of the good. Aristotle speaks of man as an active being, who differs from all other creatures by his ability to choose freely. Choice is not only pure knowledge, but also an aspiration, a volitional act.
After all, for Aristotle, as well as for Platon, the perfect knowledge of the good must guide our actions and aspirations for virtues, and freedom must ultimately be understood as perfect autarky. Autarky manifests itself in the order of the policy, based on the principles of reason, so that the freest person is most bound by knowledge of the order of the policy.

However, it should be noted that Aristotle still managed to go beyond the Greek polis thinking. For Aristotle, the highest autarchy of the sages was the possession of happiness, i.e., the ability to live in accordance with the wishes of their own will (and the sages all agree with Logos).

We can say that Aristotle, like the Stoics, defined freedom, which had its precondition of responsibility, only as freedom of human actions or freedom of spontaneity. Human action is free in the sense that it proceeds from "own action" or is "sua sponte", as the scholastic said [5, 16].

Aristotle speaks of freedom as arbitrariness, and in "Nikomakh's Ethics" he discusses the connection between freedom and the notion of virtue. Involuntary are those our actions, which are committed under the influence of servitude - either under the influence of natural forces or under the influence of someone else's power, as well as in ignorance (when a person has no idea about the possible consequences of his actions). However, even actions considered arbitrary are not always carried out of their own free will (consciously).

Aristotle classifies an individual's arbitrary actions as follows: they are intentional or deliberate actions, committed by a person deliberately. The choice is made by the person himself and depends on the means to achieve the goal and the ways to turn these means into reality.

Aristotle's philosophy is also associated with an important moment in thinking about human freedom of will. $\mathrm{He}$ understood "volitional" as the self-determination of the mind, which allows us to talk about the "spontaneity" of arbitrariness and to derive the notion of the 
independence of the decisions of the mind from the notion of the decision itself. Aristotle interprets "Voluntary" as something that depends directly on the will of the individual.

One of Aristotle's important ideas was that he spoke of the mind as the source of specific causality, different from nature or chance. Arbitrariness is the cause of what is in the action being performed, and imputation refers only to reasonable actions. As Stolyarov notes, the concept of "guilt" gets Aristotle a subjectivepersonal meaning. Aristotle introduces such concepts as "will", "choice" (or "solution"), "arbitrary", "goal", etc.

All these categories were "accepted by the Stolyarov, and through her passed to the Roman authors and to the patriot" [2, 504].

After the collapse of the Greek polis, the concept of freedom begins to correlate more and more with the inner freedom of the individual.

Therefore, the question of the existence and mode of existence of an individual comes to the foreground. In the ethics of Stoicism (Chrysip), the freedom of the individual is that he or she can with his or her mind and will confront fate as something that is beyond his or her control. Stoics, in a certain sense, developed Plato's ideas.

They believed that if evil on earth cannot be a property of cosmic causality, it comes only from man.

Stoics believed that the decisions of the mind are the source of spontaneous causality and in this sense - cannot be free. However, the decisions of the mind must be free so that its intentions can be realized.

Epicurus seeks to remove arbitrariness from the field of external determinism and "tie" it to the arbitrariness of the action. But by putting the determinism of fate in the place of the determinism of chance, Epicurus could no longer justify the foundations of the moral decision.

In Seneca's opinion, freedom is the "superiors' essence" of a peculiar "counterbalance" to the lower motives of our soul, various affects and life circumstances. In its highest manifestation freedom is manifested in the will of God - freedom is our "royal" privilege - to see ourselves free in obedience to God.

In the highest degree, the stoic notion of "inner" freedom is developed by the Epicyte. Freedom is a "work" and the highest good in man. Since what we know is inside us, freedom (in the negative sense) is to "let go" what is "outside of us". Pozivno Epicyte understood freedom as the desire of his own aspirations ("free is the one with whom everything happens according to his own free decisions") [7, 9].

And yet, it is necessary to "follow God", or rather - the will of God. This is what makes the Stoics' dialectical understanding of freedom particularly acute: thanks to obedience to God, a human being becomes free in relation to God, i.e. one can say that a human being himself becomes like a god.

The idea of moral autonomy and the link between freedom and sanity of action was particularly vividly revealed by the Plato. Plato rose the question of an existence whose way of existence is freedom, an existence that affects its own existence. Men's essence does not coincide with self-control, so we are not "masters" of his being.

A human being himself cannot be free, only eternal in a human being - his soul can be free. The body is bound by the laws of nature as well as the laws of society.

At the same time, Plato distinguished between freedom of complete domination over itself (freedom proper) and a lower level of freedom-freedom of choice. According to the view of Plato, human freedom finds its perfect form in man's aspiration for the One.

The Plato's reflections on human freedom and internal responsibility have a clear legal connotation. In Antiquity, morality and law did not yet differ from each other, as it was done later in the Middle Ages and New Age.

The ontological justification of freedom in Neoplatonism will be continued to the greatest 
extent in Yamvlich and will be transferred to the theological plane.

In Yamvlikha, it is not a question of free action or deeds, but of liberation in the sense of salvation from the world of necessity (nature) and of moving towards the most powerful being towards the divine.

Men in this act of theurgy plays the role of "concomitant cause", the decisive thing here is only to transfer themselves under the influence of "divine power", when the soul of the individual will be able to open up in the highest degree.

The supreme act of human freedom is the cognition of God - thus the absolute freedom of divine influence on human spirit comes to its perfection.

Proclus's reflections on freedom take the following form: in his opinion, only "the spiritual nature itself is free in itself and on itself".

Freedom is directed at itself as its "own good" and needs nothing more.

Freedom is something that is proportional to the support of the being of spirit, it is a "free will to serve" God in the sense of Plato. The concept of Proclamation of the concept of freedom is the last among the ancient philosophers engaged in the aporion of "freedom and necessity" and allows to proceed to the scraping of this concept in the Middle Ages.

The notion of the place of the individual in the world, or society, is intertwined with the various aspects of the notion of the recognition of human rights and freedoms; the spirit of freedom required theoretical justification and found it in the form of philosophical reflection. This reflection is evidenced by the views of ancient philosophers on its specificity. They are illustrated in a comparative analysis of the Socratic schools of thought, such as Democritus, Cynics, and Cyrenaics, Plato and Aristotle, the Epicurean and Stoic Hellenic schools of thought.

Ancient thinkers exercised the reflection of freedom in relation to the analysis of human activity and behavior. As a result, each interpretation of freedom and its aspects are determined by the specifics of a particular sociocultural context. In ancient times, as a universal of culture, freedom occurs in the form of an arbitrary and non-arbitrary classification of activity, subject to individual choice, intertwined with law and moral norms, natural factors, and moral beliefs.

The comparison of the peculiarities of the philosophical reflection of freedom, which is the universality of culture in antiquity, illustrated that it was understood as the interrelationship of the analysis of human activity and behavior. The relevance of freedom is expressed in three main degrees:

1. in daily consciousness, in mythological representations;

2. at the theoretical level in legal norms and legal codes;

3. the philosophical concept of freedom in the teachings and doctrines of the thinkers of the Antiquity.

The Middle Ages era, with the Bible at the center of philosophical debate and divine revelation, radically changed the very question of human freedom. As Plotnikov noted, Christianity has made two decisive turns in human thinking:

it radically transformed the moral imperative, placing the good of the neighbor at the center of consideration - so the sphere of ethics was separated from the sphere of law;

Christianity "modified" theodicy, replacing imperial cosmic determinism with unique divine causality [2, 505].

Therefore, even in the text of the Bible itself it is possible to trace a consistent modification of the meaning of the idea of freedom as a philosophical category. Thus, in the Old Testament it is only a question of Yahweh's freedom as a liberator of the prisoners from detention - it was Yahweh's "holy" service.

It is clear from this that the Old Testament interpretation of the concept of freedom represents an understanding of freedom not as an attribute of divine existence, but only as a corresponding activity for the liberation of specific people. 
And although the freedom of people is not directly mentioned in the Old Testament texts, we can see that the very nature of the divine commandments, which speak about sins and punishments for these sins, as well as repentance, contains in a hidden form of some rudiments of freedom (and above all freedom of decisions).

The traditions of the Old Testament are continued in the New Testament: the act of liberation of God reaches its peak in the act of liberation of Jesus Christ.

Philosophical reflections on the concept of freedom in the Middle Ages are first to be found in Philon of Alexandria. At first, he developed stoic motifs about the concept of freedom in his texts; later Philon of Alexandria had already used Plato's ideas.

In Philon's opinion, only a god is free, a single god, "one that rests on nothing" and as a "self-filling and self-sufficient" higher being. God is so free even in relation to himself that he can be the creator of the universe without being attracted to any demiurge.

After all, God combines both the good from which everything has come and the power through which he rules the whole world. A free man is one whom God gives freedom to. God can give freedom to man, because he created man as an indestructible spiritual essence.

When researchers try to analyze medieval philosophical texts in detail, it is very difficult for them to separate theological concepts from philosophical statements properly. Very often medieval philosophers have traditional philosophical concepts of ancient Greek origin "filled" with religious content alien to them [6, 1076]. For example, in the presentation of ancient Greek philosophy, Apologets often substitute the original concepts with theological concepts.

Thus, Justinus [Justinus] in his "First Apology" develops a peripathetic doctrine of

Such a choice is not only an indication of our bad and good deeds, it characterizes our whole being. Since the good (or god) is identical to being, and evil to not being, the person who freedom and formulates the thesis that "one person, based on his fate, becomes good and the other evil". Another statement by Justinus says that a person, "based on his or her free decision, is able to both create a just one and avoid it. Thus, he has a clear view of the question of freedom as a free choice. Gradually, Justinus departed from ancient notions of freedom and began to question the question that was central to all medieval philosophy: the question of the compatibility of divine predestination and human freedom.

\section{Result and discussion}

The antinomic nature of the relationship between divine grace and human freedom is particularly pronounced in the texts of Clement of Alexandria. Clement distinguishes between the natural inclination of people to do good and the very "freedom" in the sense of apatheia. And if in the first case the sense of human acts is proved, then in the second case it is clearly seen that the true freedom is only that freedom to which only the god is capable.

Divine will be manifested in the fact that we choose the good in our desires and thus free ourselves. Arete, therefore, means salvation, because the divine order of things is such that man as a free essence from nature, i.e., naturally strives for good. "Free action" consists in giving oneself to the divine will.

Origen develops the doctrine of Clement of Alexandria and says that possession of freedom and distinguishes people from all non-spiritual entities. Our ability to be good or bad people is not in our nature or the game of chance (Pathum).

This ability is only the result of our free choice. According to Origen, people have a natural ability to distinguish between good and evil, and we can also operate with these two concepts. However, the ability to choose good and to reject evil is already a very special act.

avoids participating in doing the good (being) rolls down into nothingness.

Later on, the emphasis shifts somewhat, and already in Gregor von Nissa [Gregor von 
Nissa], as well as in Pseudo-Dionysius, the question of the meaning of human life becomes central, consisting in the knowledge of God, divine knowledge and predestination.

According to Gregor, the possession of freedom in humans is a necessary prerequisite for man to achieve comprehensive knowledge of divine knowledge. Here we can see one interesting nuance: if the monk Gregor talks about unlimited freedom of will of man, then in the speculative and mystical theology of the next century, PseudoDionysius - it is about freedom as a turn of man to the super-divine as the unity of all things" [6, 1080].

Gradually, medieval philosophy began to raise the question not only about the divine essence, but also about human nature. Thus, Maximos [Maximos der Bekenner] distinguishes in the will of man created "in the image and likeness of God" two following moments: the "natural will" of man as a free manifestation of his essence and the "consciously directed will" of the individual to cognize his own essence.

The distinction made in theology about the dual will of Christ - divine and human - allows Maxim Su to formulate the human "dimension" of freedom itself: freedom is the divine wisdom of human existence, existence as a person. Freedom arising from human nature means the exercise of divine wisdom in the activities of an individual.

Nemesias [Nemesias], who relied on the Aristotelian teachings on the inseparability of the ability to make free decisions from the spiritual nature of man, raises the question of theodicy and explanation of the existence of evil in the world. Nemesias believes that God, as creator of man, can only be responsible for the appearance and existence of evil in the world. It is out of man's ability to make decisions, in other words, to choose, out of man's freedom that evil emerges.

At Augustine's it is especially precisely possible to trace an idea that ratio of divine will (grace) and human will (or, in Augustine's terminology, freedom) is both initial point and the purpose of all reflections on freedom. Augustine distinguishes volunteers as the main active ability of human spiritual nature from libertum arbitrium (freedom of choice - lat.) as the highest expression of this ability in the act of decision-making. This distinguishes man as a spiritual entity from the natural world.

In his early treatise "On the Free Solution" Augustine examines the theodicy and relies on the idea of rationalistic ordering of the world. Augustine follows completely classical traditions of medieval theology and religious philosophy when specifies that the god is not responsible for evil in the world, as the only source of evil on the Earth is human will. The existence of morality only becomes possible when the subject is free from the conditions of external causality; the individual must also be able to choose between good and evil. Morality in this case is to follow a man's moral duty. In Augustin's opinion, the idea of moral law can act as a motive for human behavior.

Later on, this scheme was replaced by the concept of predestination, which reaches its conclusion in anti-Pelagian treatises and leads to "a final break with ethical rationalism" [2, 505].

In Augustine's opinion, man is free to choose not to sin, to resist temptation and lust. Man can only be saved by the grace of God. Man's own choice depends on whether he accepts sin or refrains from it.

Augustine believes that the will is "the cause of itself" and can be determined through this self-evident cause. This means that the unconditional freedom of man, inherent in man as a spiritual being and elevating him above the rest of the natural world, leads the individual to become a person, a person created by the creator. At the same time, a person's will can be directed both to lowly motives (cupiditas) and to his highest manifestation - love for God (caritas=Motus ad fruendum Duo).

The medieval understanding of freedom is largely based on Augustine's basic ideas about "De libera arbitrio". At the same time, some aspects of Augustine's teachings are being modified. For example, Anselm of Canterbury interprets freedom arbitrium not as a neutral 
ability of man to arbitrariness, but as a freedom of man aimed at achieving their good. Aristotle's ideas about the self-mobility of the soul and the self-determination of the mind are put at the centre of the schololists' consideration - at this time Augustine's reflections are not in demand.

Interestingly, Anselm of Canterbury and Thomas Aquí have a concept of freedom that reaches an even higher degree of abstraction, and freedom begins to be seen as a purely intellectual ability, close to the ability to judge. The will is free from any manifestations of external necessity and its solution is a necessity for itself.

Anselm of Canterbury defines freedom as the goal that the mind shows us, and the will chooses that goal. Thomas Aquinas, strongly influenced by Aristotle's ideas about the psychology of choice, understands freedom as the ability of the will to find the means to achieve the chosen goal, and the goal itself was not a liberum arbitrium. But for Thomas, the notion of freedom was not exhausted, as it may seem, by the "valueneutral" interpretation of freedom as a freedom of choice. He speaks about the modality of freedom of choice and about the essence of freedom as an independent essence directly related to God in his creation of the good. This understanding of freedom brought all the scholarly attention to the question about the metaphysical roots of freedom. Bonaventure, for example, interprets freedom as the independence of an entity endowed with the mind.

In general, we can state that at the end of the Antiquity era there were two main traditions of considering the notion of freedom [6, 1082]. In the mystical theology of the Christian East, freedom was interpreted as a condition and execution of "Theosis" through the exaltation to the experience of God - this line goes from John Scott Erigena to Nicholas Kuzansky. The other line regarded freedom as an immature dialectical notion about the relationship between nature and divine grace - these issues were handled by both Occcam and later Martin Luther.

Ockham is not interested in the question of whether human will be free in principle. He sees freedom already, in terms of today's philosophy, from a "theoretical-cognition" point of view. Ockham believes that freedom cannot be justified by reasoning - freedom can only be studied as a phenomenon of an individual's inner experience. The question of God's freedom is not treated as a question of the philosophical mind, but as an area of religious faith.

A new aspect of Ockham is the question of what man himself can do - before God intervenes. The answer to this question from all subsequent scholastic scholars sounds quite in the spirit of medieval religious philosophy - freedom can lead a person to an act of perfect love for God and eventually achieve divine mercy.

\section{Conclusion}

It is important to note that this very idea of medieval scholasticism made it possible to take the next step in the development of the notion of freedom in philosophy. Such a theological evaluation of freedom should have been supplemented by a psychological notion of freedom as an absolutely undetermined will. This is where the humanist understanding of freedom as freedom in relation to God comes in. The scholastes considered the "creator-created" ratio without questioning the primacy of God's will.

In the Middle Ages, freedom was understood as created by god. Then the accents change significantly, and the Renaissance philosophy already interprets freedom as the selfcause of people in relation to God.

Martin Luther comes to replace the liberum arbitrium. In Luther, the problem of human freedom is considered, although theologically speaking, but is already in line with other topics: law, merit, redemption, etc. At the same time, as we know, Luther did not adhere to the rigid framework of scholasticity and did not try to show that man gets his freedom as a gift of God.

Luther's break with dogmatic theology can be seen in that. Since Luther is trying to justify human freedom by purely philosophical methods, we can argue that this is already a humanist understanding of the category of freedom [4, 
1087]. In his works, Luther considers divine acts on the same metaphysical level as human actions and freedom. It can therefore be said that he is the direct precursor of Renaissance ideas.

Thus, it is possible to notice that the modern understanding of the idea of freedom, as well as the ideas of law, justice and civil society take their roots in the philosophy of Antiquity and the Middle Ages. The subsequent development of philosophical and political thought only develops in more detail the categories of the idea of freedom, as well as "applied" aspects of this concept, on the basis of which modern democratic states are built.

\section{References}

[1] New philosophical encyclopedia in 4 volumes / ed. V. Stepin, A. Guseinova, G. Semigina, A. Ogurtsova. M., 2010.

[2] Stolyarov, A.A. Free will as a problem of European moral consciousness. Essays on History: From Homer to Luther. M .: GrecoLatin office of Yu.A. Shichalina, 1999.206 p.

[3] Conze, W. Freiheit // Brunner, O., Conze, W., Koselleck, R. (Hgg.) Geschichtliche Grundbegriffe. Historisches Lexikon zur politisch-sozialen Sprache in Deutschland. Bd. 2. Stuttgart, 1998. S. 435 f.

[4] Pesch, O. Freiheit // Ritter, J. (Hg.) Historisches Wörterbuch der Philosophie. Bd. 2. Basel / Stuttgart, 1972. S. 1087.

[5] Steinvorth, U. Freiheitstheorien in der Philosophie der Neuzeit. Darmstadt, 1987.

[6] Warnach, W. Freiheit // Ritter, J. (Hg.) Historisches Wörterbuch der Philosophie. Bd. 2. Basel / Stuttgart, 1972.

[7] Epiktet, Diss. 1,12,9.

[8] Rakhimdjanova D.S. Features of the freedom issues in the Plot's philosophy. International Journal of Advanced Science and Technology. Vol. 28, No. 16. (2019), pp. 1560-1564. ISSN: 2005-4238 IJAST

[9] Ruzmatova G. Eastern melodies in the text of Plato // International Journal of Recent Technology and Engineering. Vol. 8, Issue-
2S6, July, (2019). -P. 444-448. IJRTE. ISSN: 2277-3878.

[10] Ruzmatova G. Comparativist analysis of Representations about Will in View of Friedrich Nitzsche and Jalaliddin Rumi // International Journal of Psychosocial Rehabilitation, Vol. 24, Issue 04, 2020. ISSN: 1475-7192. -P. 3215-3227.

[11] Taho-Godi A.A. Greek mythology. Moscow, Art, 1989, 304 p.

[12] Makovelsky A.O. Ancient Greek atomists. Baku, Avesta, 1946, p. 360, 361.

[13] Reader on the history of philosophy. At 3 o'clock, Part 1. Moscow, Center, 1998, p. 126, 128, 223.

[14] Anthology of world philosophy. In 4 volumes.Vol. 3.Moscow, Mysl, 1971, p. 361.

[15] Brambo R.S. Philosophers of Ancient Greece. Moscow, Centerpolygraph, 2002, p. 183.

[16] Greek sage Diogenes. Moscow, Mediator, 2010, p. 37. Humanitarian bulletin \# 2 • 201813

[17] Anthology of cynicism. Moscow, Nauka, 1984, p. 14.

[18] 18. Losev A.F. History of ancient aesthetics. In 2 volumes. T. 2. Moscow, Art, 2003, p. 242. 